\title{
DAILY AMPLITUDE OF AIR TEMPERATURE IN POLAND AND BULGARIA - A COMPARATIVE STUDY
}

\author{
Jakub Szmyd, Pawel Milewski \\ Institute of Geography and Spatial Organization \\ Polish Academy of Sciences \\ Twarda 51/55, 00-818 Warsaw, Poland \\ j.szmyd@twarda.pan.pl,pmilewski@twarda.pan.pl
}

\begin{abstract}
The work presented here aimed to compare daily amplitudes of air temperature in Poland and Bulgaria, by reference to data from 36 meteorological stations (i.e. 18 from each country) over the period 2000-2012. It proved possible to demonstrate that the average temperature amplitude at the stations in Poland is $2-3^{\circ} \mathrm{C}$ smaller than that noted for Bulgaria, with the spatial differentiation characterising such averages also being significantly more limited in Poland. Where the annual course for average amplitudes in air temperature in Poland are concerned, there are two maxima and two minima to be noted, as compared with one maximum and one minimum in Bulgaria. The highest values for average daily amplitude in air temperature to be noted in Poland are those typical for May, while highest values in Bulgaria fall in August. The differences between Poland and Bulgaria also manifest themselves in the markedly greater frequency of occurrence of large $\left(>20^{\circ} \mathrm{C}\right)$ values for temperature amplitudes to be noted in Bulgaria.
\end{abstract}

Keywords: amplitude, air temperature, Bulgaria, climatology, Poland.

\section{Introduction}

Amplitude of air temperature is defined as the difference between the maximum and minimum air temperatures occurring at a given place over a given period of time, e.g. a day or a year. A feature typical for this indicator is marked spatial differentiation, as well as dependence on many different geographical and meteorological conditions.

Where daily amplitude to air temperature is concerned, values are found to vary in relation to latitude, with amplitude decreasing as one moves through temperate latitudes from areas close to the Tropics up to the Arctic Circle. In turn, higher altitudes above sea level are again associated with more limited amplitudes of temperature, given a weaker influence of terrain on the atmosphere where air is of lower density. Daily amplitude of air temperature is in turn greater over land than water, in reflection of soil's lower heat capacity. Similarly, differences in water content are reflected in the greater amplitude typical for dry, as opposed to wet, ground, as well as for areas lacking plant as compared with vegetated areas. Finally, in comparison with plain areas, convex landforms are 
characterised by a more limited daily amplitude in air temperature, while concave landforms manifest greater amplitudes (Tamulewicz 1997).

It is cloud cover that can largely determine daily amplitude of air temperature. Clouds reduce amounts of solar radiation during the daytime, while increasing downward atmospheric radiation at night. Taken together, these actions can produce a marked decrease in thermal contrasts over a 24-hour period. A clear relationship between the size of the amplitude and wind speed can also be demonstrated, as the movement of air increases the circulation of heat in the atmospheric boundary layer, thereby tending to reduce amplitudes. In some cases, the periodicity to daily changes (and therefore amplitudes) in air temperature, may be disrupted by non-periodic changes, e.g. by advection of cold or warm air at different times during the day.

Despite or because of all these influences, daily amplitude of air temperature is a widely-applied climatic indicator characterised by its simplicity. It serves as a basic measure of the daily dynamics to air temperature, while also providing an effective representation of regional characteristics to thermal conditions. It is often used to assess the impact of oceans or land on the atmosphere in specific areas, being one of the key indicators of continentality of climate (Chromow 1968, Woś 2010).

In bioclimatology, data on daily amplitudes of air temperature are used to assess the intensity of thermal stimuli, given that even small and short-term changes in air temperature in the course of a day induce the body into effort associated with the need to adapt to new thermal conditions. Where changes are small, they are important in the tempering of the body, which can become more resilient, and thus better able to adapt easily and quickly to ever-more-intense stimuli (KozłowskaSzczęsna et al. 1997). Changes in air temperature have a significant impact on human well-being during prolonged exposure outdoors. Large thermal contrasts in the course of a day seem to favour the activation and development of many diseases, e.g. a cold (Kozłowska-Szczęsna et al. 2004). The so-called meteoropaths are also more likely to experience symptoms such as headache, general body weakness, drowsiness or emotional instability.

The aim of the work described here has been to compare daily amplitudes of air temperature in Poland and Bulgaria, in particular in regard to their spatial distribution. This paper thus complements two other works contained in this publication: on the heat stress that may occur during field activities in agriculture in Poland and Bulgaria (Błażejczyk et al. 2015), and on the adjustment processes in the human body associated with changes in meteorological conditions as travel between the two countries takes place (Milewski \& Szmyd 2015).

\section{Materials}

The dataset used in this study comprised daily maximum and minimum air temperatures from the years 2000-2012 from 36 meteorological stations, i.e. 18 each from Poland and Bulgaria (Fig. 1). The source of information was the online database of the National Climatic Data Centre, National Oceanic and Atmosphere Administration (http://www.ncdc.noaa.gov). The list of meteorological stations in each of the countries includes two high-mountain stations and three seaside stations. In Poland these were respectively Kasprowy Wierch (Tatra Mts.) and Śnieżka (the Sudetes), as well as Szczecin, Koszalin and Gdańsk (Baltic Sea); while in Bulgaria they were Musala (Rila Mts.) and Botev (Balkan Mts.), as well as Shabla, Varna and Burgas (Black Sea). The remaining stations (13 in each country) are distributed fairly evenly across the territory of Poland and Bulgaria, representing different physiogeographic regions. The stations (away from mountains) located at the highest altitudes are 
Sofia and Kyustendil in Bulgaria (at 595 and 527 m a.s.l. respectively), as well as Kłodzko in Poland (357 $\mathrm{m}$ a.s.1.). Other stations are located at elevations below 350 or below $300 \mathrm{~m}$ a.s.1. in the cases of Bulgaria and Poland respectively. In line with these small overall differences in station altitudes between Poland and Bulgaria, this factor can be assumed to not have too much impact on variation in the distribution of daily amplitudes of air temperature.

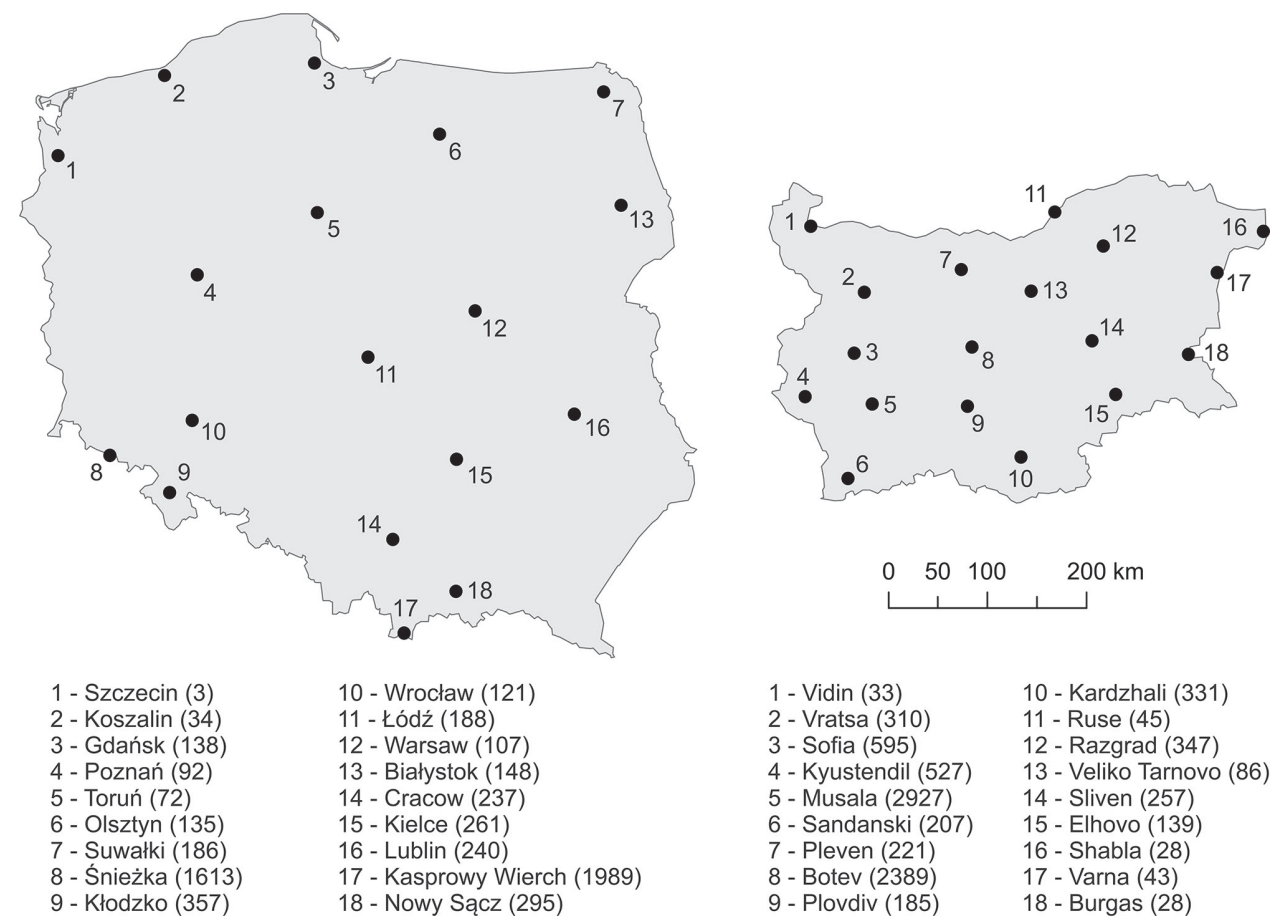

Figure 1. Locations of meteorological stations used in this study. Numbers in parentheses represents heights above sea level in meters

\section{Results}

The feature proving typical for average daily amplitudes of air temperature noted in Poland in the years 2000-2012 was limited spatial differentiation (Fig. 2). Over most of Poland, the average amplitude over 24 hours was in the range 8 to $10^{\circ} \mathrm{C}$. Lower values were reported by the sea (with Koszalin noting $7.3^{\circ} \mathrm{C}$ and Gdańsk $7.7^{\circ} \mathrm{C}$ ), and in the mountains (Śnieżka $5.2^{\circ} \mathrm{C}$, Kasprowy Wierch $5.8^{\circ} \mathrm{C}$ ). Likewise, higher values for the average only characterised certain stations in the south of Poland (Wrocław $10.1^{\circ} \mathrm{C}$, Nowy Sącz $10.2^{\circ} \mathrm{C}$ ), though these were still not shown to attain statistical significance when compared with values reported for the rest of the country.

In Bulgaria, average daily amplitudes of air temperature were clearly greater than in Poland, being in the range $10-13^{\circ} \mathrm{C}$ at a majority of stations. The highest values for the average in fact characterised Kyustendil and Veliko Tarnovo (13.3 and $12.8^{\circ} \mathrm{C}$ respectively). Large values for averages are characteristic primarily for stations located in the western and southern parts of Bulgaria. As in Poland, the lowest average for daily amplitudes in air temperature were found for stations located 
in the high mountains. A relationship similar to be noted for Poland was also detected, given that a mountain station located at greater altitude reports a larger average amplitude than one located lower down (Musala $6.2^{\circ} \mathrm{C}$, Botev $4.8^{\circ} \mathrm{C}$ ). Low average values also characterised coastal stations, like Shabla at $8.2^{\circ} \mathrm{C}$ and Burgas $10.1^{\circ} \mathrm{C}$ ), as well as those located a short distance from the sea (Razgrad $9.7^{\circ} \mathrm{C}$, Sliven $10.0^{\circ} \mathrm{C}$ ).
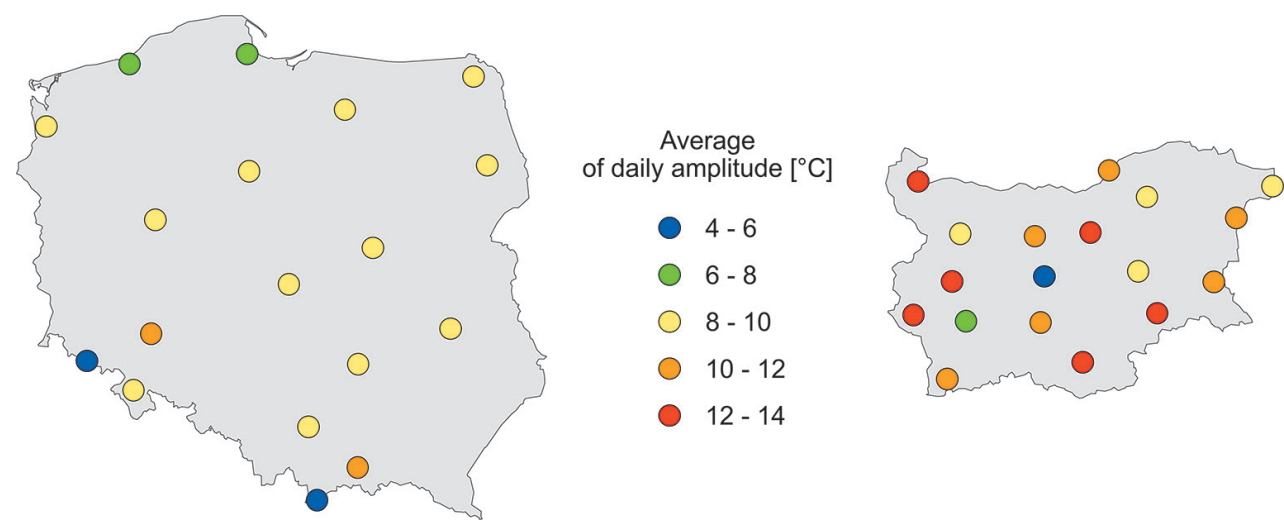

Figure 2. Averages for daily amplitudes of air temperature in Poland and Bulgaria (2000-2012)

Variability to the averages for daily amplitudes of air temperature in Poland during the course of a year (other than at high-mountain stations) is well developed (Fig. 3). The highest values for these averages occur in May (only in Kłodzko in August), ranging between $10.0^{\circ} \mathrm{C}$ in Koszalin and $13.0^{\circ} \mathrm{C}$ in Białystok. Amplitudes only slightly smaller are typical for August, while the smallest characterise January or December (November in Suwałki only), though they are in the range from $4.2^{\circ} \mathrm{C}$ in Gdańsk to $7.1^{\circ} \mathrm{C}$ in Nowy Sącz. In a majority of months, the differences between the highest and lowest averages for daily amplitude of air temperature at stations in Poland (away from coastal or high-mountain areas) are small, at below $2.5^{\circ} \mathrm{C}$ (with a minimum of $1.3^{\circ} \mathrm{C}$ in July). Spring values for 24-hour temperature amplitude are greater than those in fall, because night temperatures at this season of the year are lower than those characterising autumn.
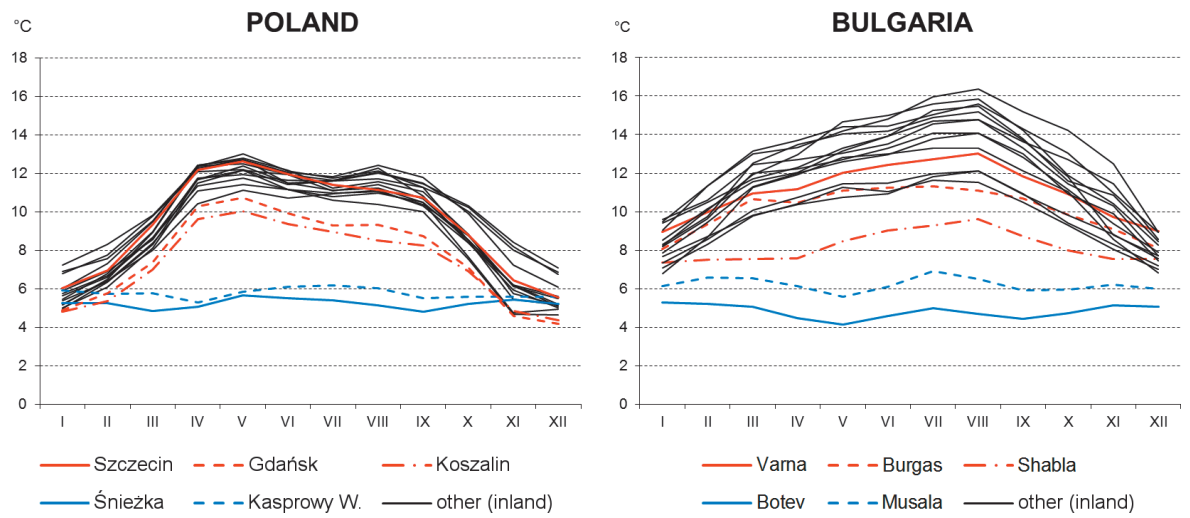

Figure 3. Annual course for average amplitudes of air temperature in Poland and Bulgaria (2000-2012) 
The averages for daily amplitude of air temperature in Bulgaria (away from coastal and highmountain stations) are greater than those for Poland in each month of a year, typically by $2-3^{\circ} \mathrm{C}$. Small differences (of approximately $1.0^{\circ} \mathrm{C}$ ) in averages between the countries appear in April and May, while averages are seen to diverge most (to approximately $3.5^{\circ} \mathrm{C}$ ) in November. The variability to amplitudes during the year is markedly different in Bulgaria as compared with Poland. The annual courses for averages there have a single maximum, occurring in August (or in July in the cases of Burgas and Razgrad only). The average amplitude at the time of these maxima is in the range $9.6^{\circ} \mathrm{C}$ in Shabla to $16.4^{\circ} \mathrm{C}$ in Kyustendil. As in Poland, annual minimum values characterises January or December, when average amplitudes are as small as $6.8^{\circ} \mathrm{C}$ in Ruse to $9.0^{\circ} \mathrm{C}$ in Varna. In most months of a year, the difference between the highest and lowest averages for daily amplitude of air temperature are greater at stations in Bulgaria (away from the coast and high mountains) than those in Poland, exceeding $3.5^{\circ} \mathrm{C}$ (and reaching a maximum of $4.9^{\circ} \mathrm{C}$ in October).

The annual courses for average amplitudes of air temperature at high-mountain stations in both Poland and Bulgaria are characterised by a high degree of similarity that stands in contrast to the markedly divergent courses characterising lower-altitude stations. The mountains report smaller average amplitudes than the lowlands, especially in the summer, though there are only very small variations during the year. The difference between the highest and lowest monthly averages for amplitude were found to range from $0.9^{\circ} \mathrm{C}$ at Śnieżka to $1.3^{\circ} \mathrm{C}$ at Musala. In this regard, the conditions characterising coastal areas in Poland and Bulgaria can be regarded as intermediate between those at the peaks of mountains or else in areas located in the hinterland.

In Poland, the days arising most frequently in the course of a year are those on which the air temperature amplitude is of between 5 and $10^{\circ} \mathrm{C}$ (Fig. 4). Such days occur most frequently of all in the case of Kasprowy Wierch (where they account for $54.2 \%$ of the total). Only slightly fewer such days (45.2\%) are reported on Śnieżka, though the latter is the only station in Poland at which days with even smaller amplitudes $\left(<5^{\circ} \mathrm{C}\right)$ are found to prevail (on $51.0 \%$ of the total).

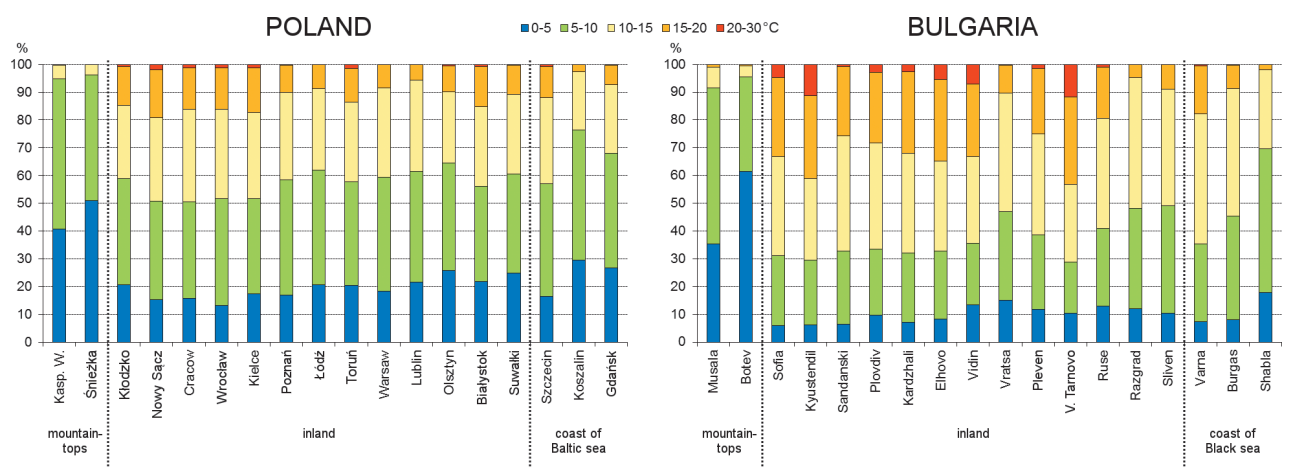

Figure 4. Frequency of occurrence (\%) of days with specific range values for daily amplitude of air temperature, in Poland and Bulgaria (2000-2012)

A large number of days characterised by temperature amplitudes in the $5-10^{\circ} \mathrm{C}$ range is also typical for the coastal stations (Koszalin 46.7\%), as well as those situated in central Poland (Poznań 41.4\%, Warsaw and Łódź each 41.0\%). Moreover, at each of the analysed stations in Poland more than half of the days in the year report amplitudes in air temperature of less than $10^{\circ} \mathrm{C}$. The value for this indicator is lowest in Cracow (50.5\%), and highest at the coastal stations (Koszalin 76.4\%) or else 
those in the high mountains (Kasprowy Wierch 94.8\%, Śnieżka 96.2\%). Days featuring an amplitude of air temperature greater than $15^{\circ} \mathrm{C}$ are a rarity in Poland. However, they occur most frequently at Nowy Sącz (on 19.1\% of days in the year), notwithstanding occurrences at the majority of other stations arising less than $15 \%$ of the time. Days with an amplitude above $20^{\circ} \mathrm{C}$ occur occasionally only, there being no such cases at all at the high-mountain stations in the period 2000-2012.

Across much of Bulgaria, the days occurring with greatest frequency are those reporting an amplitude of air temperature at a given station in the 10 to $15^{\circ} \mathrm{C}$ range. The greatest numbers of such days characterise Razgrad and Varna respectively (occurring 47.0 and $46.9 \%$ of the time, respectively). At the high-mountain stations the conditions may resemble those at Śnieżka and Kasprowy Wierch in Poland, given that more than half of the days of the year feature amplitudes of temperature below $10^{\circ} \mathrm{C}$. The frequency of occurrence of days with a specific range of amplitudes also proves to be similar at coastal stations in Bulgaria and Poland, though Varna and Burgas report a greater number of days on which the amplitude is of $10-15^{\circ} \mathrm{C}$. Days with an amplitude above $15^{\circ} \mathrm{C}$ occur more often in Bulgaria than in Poland, to the point where they extend to around $42 \%$ of the whole year. In the case of Kyustendil and Veliko Tarnovo. Days with an amplitude above $20^{\circ} \mathrm{C}$ occur only very rarely in Poland, while each of the selected stations in Bulgaria saw such days arise at least once in the period 2000-2012 (except at high-mountainsites). The greatest numbers days of this kind were recorded in Kyustendil and in Veliko Tarnovo, where they account for about $11 \%$ of the days in the year.

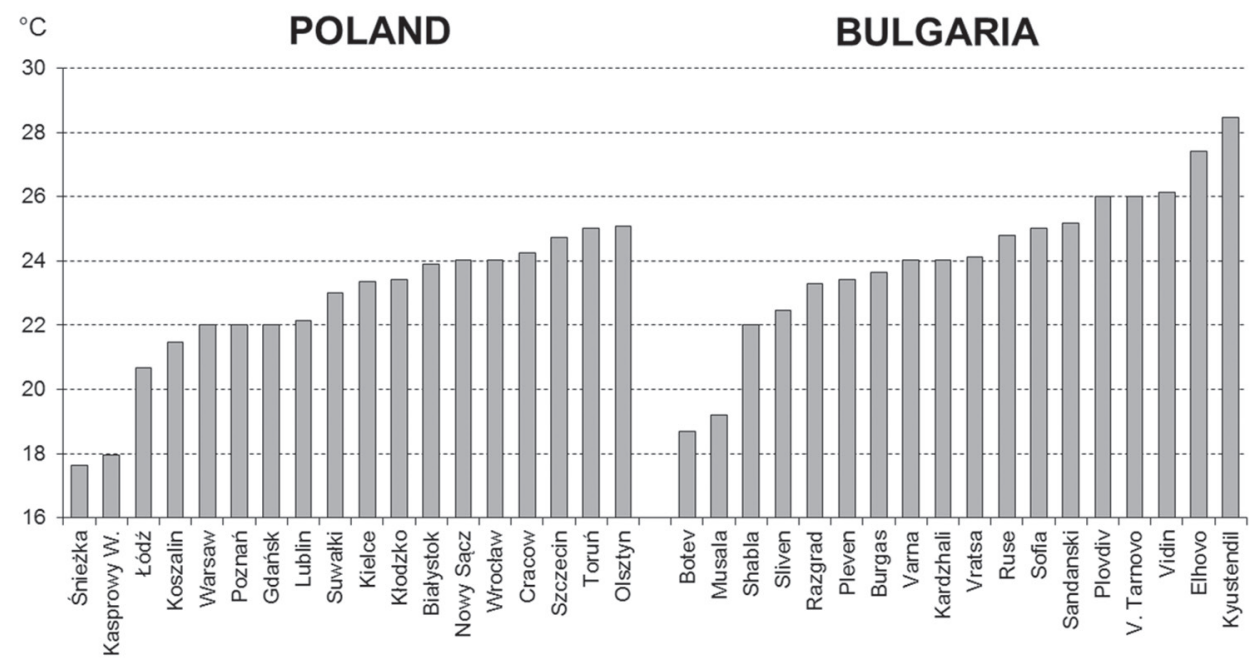

Figure 5. Maximum daily amplitudes of air temperature in Poland and Bulgaria (2000-2012)

The highest daily amplitude of air temperature across the whole $2000-2012$ period was the $28.5^{\circ} \mathrm{C}$ reported on $31^{\text {st }}$ October 2010 in Kyustendil (Fig. 5). Only slightly smaller is a $27.4^{\circ} \mathrm{C}$ recorded on 10 May 2003 for the amplitude in Elhovo. In Bulgaria, large (above $25.0^{\circ} \mathrm{C}$ ) maximum values for daily are mainly typical for stations located in the western and southern parts of the country, while there are smaller maximum values in the east (Shabla $22.0^{\circ} \mathrm{C}$ ). The lowest maximum amplitudes were reported from high-mountain stations (Botev $18.7^{\circ} \mathrm{C}$, Musala $19.2^{\circ} \mathrm{C}$ ). These values confirm the relationship presented, in that the thermal contrasts are smaller at Botev than on the higher peaks (Musala). It can be assumed that a large amplitude at higher-altitude mountain stations is contributed to by the 
presence of snow cover. The maximum air temperature above snow cover during a day is usually small, while the minimum air temperature can be extremely low, since snow radiates heat very well.

In Poland, the maximum values for daily amplitude of air temperature were smaller than those describing Bulgaria. The highest maximum amplitude occurred in Olsztyn and in Torun (25.1 and $25.0^{\circ} \mathrm{C}$ respectively), while the lowest at high-mountain stations (Śnieżka $17.6^{\circ} \mathrm{C}$, Kasprowy Wierch $18.0^{\circ} \mathrm{C}$ ). Relatively small values were also recorded by the Baltic Sea and in the central part of the country (Łódź $20.7^{\circ} \mathrm{C}$, Warsaw $22.0^{\circ} \mathrm{C}$ ).

Information of high practical importance concerns the part of the year in which the smallest and largest amplitudes of daily air temperature are most common. To investigate this, and to go beyond the annual courses for of averages of air temperature presented previously (Fig. 3), an analysis conducted saw each station in Poland and Bulgaria characterised by 100 days (i.e. approximately $2 \%$ of the days in the period 2000-2012 as a whole) on which lowest amplitudes of temperature were reported. For each of the datasets of this kind, the month with the largest number of such days was then determined. A similar procedure was carried out for the series of 100 days with the greatest values for amplitude recorded at each station.

Days with the smallest amplitudes of air temperature at all stations in Poland are usually recorded in January and in December (Fig. 6), i.e. in the months with the lowest averages for air temperature amplitude reported in Poland. The dates of occurrence of days of this kind are distributed spatially in a characteristic manner. In the eastern part of Poland days with the smallest amplitudes occur most often in January, while in the western part in December. In Bulgaria, as in Poland, the smallest daily amplitudes of air temperature are typical for January or December. In the western and central parts of Bulgaria, days with the smallest amplitude are usually recorded in December, while in the eastern part of the country they occur in January. The only exceptions are the stations in Shabla and Pleven, where the smallest amplitudes occur most often in April.
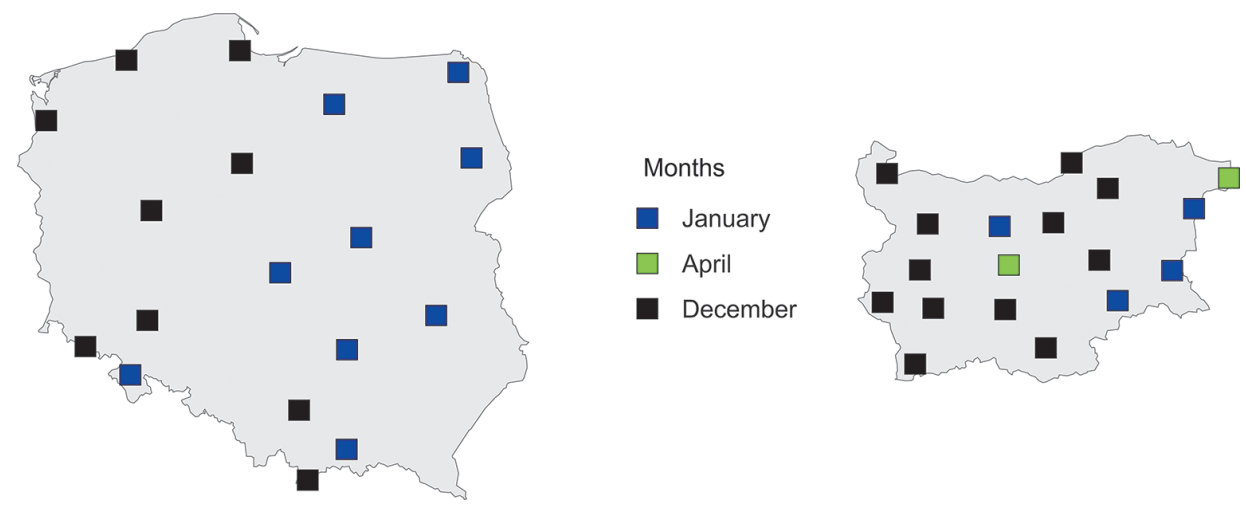

Figure 6. Months in the year with the highest numbers of days with a small amplitude of air temperature in Poland and Bulgaria (2000-2012). Small amplitude is different for each station, being defined in relation to the 100 lowest values for daily amplitude recorded in the period 2000-2012

Days with the highest amplitudes of air temperature arise in May across most of Poland's territory, which is to say the month with the highest recorded average for air temperature amplitude in Poland (Fig. 7). At certain stations located by the Baltic Sea (Szczecin, Gdańsk) or in southern Poland (Cracow, Kielce), cases of the highest amplitude were recorded most frequently in April, though in November on Kasprowy Wierch. In Bulgaria, the variation characterising months with the greatest 
numbers of days with a high amplitude of air temperature is significantly greater than that noted in Poland. At only 4 stations (Vidin, Vratsa, Kyustendil and Elhovo) are the highest daily amplitudes recorded in August, i.e. the month with the highest average for air temperature amplitude in Bulgaria. At other stations, the days with the largest amplitudes occur most often in March or July (at 8 and 4 stations respectively). At high-mountain stations, as at Kasprowy Wierch, days with the largest amplitudes are typical for November.
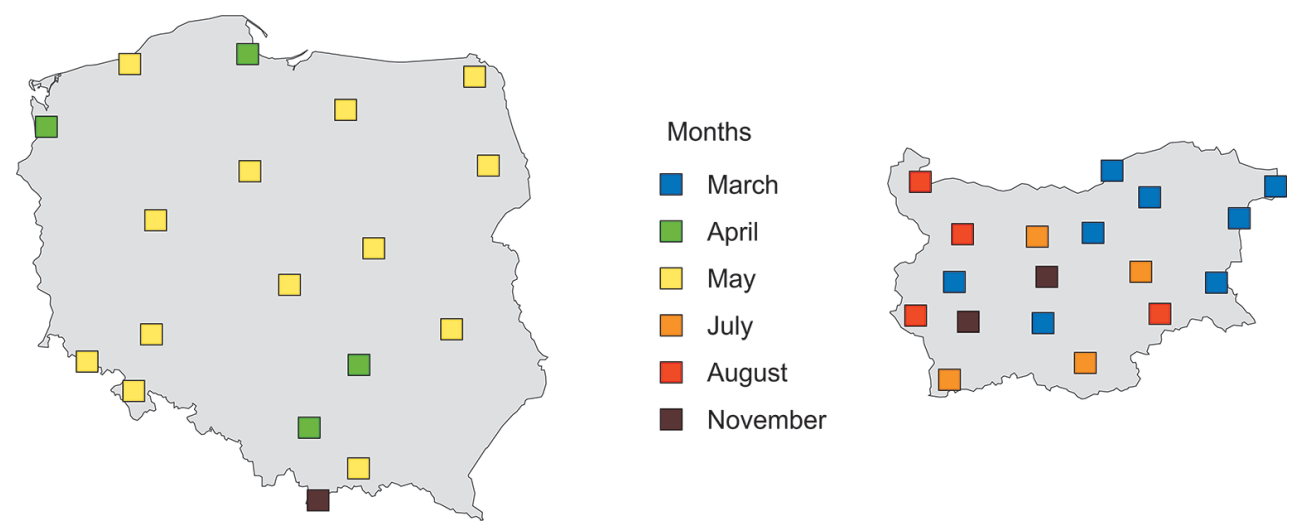

Figure 7. Months in a year with the highest numbers of days with large amplitudes of air temperature noted in Poland and Bulgaria (2000-2012). A large amplitude is different for each station being defined by reference to the 100 highest values for daily amplitude in the 2000-2012 period

\section{Conclusions}

Similarities between the daily amplitudes for air temperature noted in Poland and Bulgaria are as follows:

1. The smallest values for daily amplitude occur most frequently in January and in December. In the eastern part of Poland and Bulgaria it is in January that days with the smallest daily amplitude are recorded most often, as compared with in December in western parts.

2. Daily amplitudes are smaller at stations located in the mountains than at those in the lowlands, and are characterised by very small variations during a year.

3. Daily amplitudes are greater at mountain stations located higher up (Kasprowy Wierch, Musala) than at those located lower down (like Śnieżka and Botev).

4. Conditions of coastal stations are found to be intermediate between those characterising highmountain or other inland stations.

Differences between the daily amplitudes of air temperature in Poland and Bulgaria are as follows:

1. Average values for amplitudes at stations are $2-3^{\circ} \mathrm{C}$ higher in Bulgaria than in Poland.

2. The annual courses for averages of daily amplitude in Poland feature two maxima (a stronger one in May and a weaker one in August), as well as two minima (stronger in December and January, weaker in June and July). In contrast, those relating to Bulgaria reveal a single maximum (in August) and a single minimum (in December or in January). 
3. Spatial differentiation to daily amplitudes of temperature is significantly greater in Bulgaria than in Poland.

4. Days with a high $\left(>20^{\circ} \mathrm{C}\right)$ daily amplitude occur only occasionally during the year in Poland, while they arise more frequently in Bulgaria (at some stations in more than $10 \%$ of the year).

5. The highest daily amplitudes occur mostly in May and in April in Poland, and mostly in March, July and August in Bulgaria.

6. Across most of Poland, the highest daily amplitudes are usually recorded in the month with the largest average for daily amplitudes. This relationship is not preserved in the case of Bulgaria, however.

\section{References}

Błażejczyk K., Kazandjiev V., Degórski M., Dimitrov P., 2015. Assessment of occupational heat stress risk among agriculture workers in Poland and Bulgaria, EUROPA XXI, vol. 29, pp. 59-72.

Chromow S.P., 1969. Meteorologia i klimatologia. Warszawa: PWN, 488 pp.

Kozłowska-Szczęsna T., Błażejczyk K., Krawczyk B., 1997. Bioklimatologia człowieka. Metody i ich zastosowanie w badaniach bioklimatu Polski. Warszawa: IGiPZ PAN, Monografie, vol. 1, 200 pp.

Kozłowska-Szczęsna T., Krawczyk B., Kuchcik M., 2004. Wpływ środowiska atmosferycznego na zdrowie i samopoczucie człowieka. Warszawa: IGiPZ PAN, Monografie, vol. 4, 194 pp.

Milewski P., Szmyd J., 2015. Biothermal contrasts while travelling in or between Poland and Bulgaria, EUROPA XXI, vol. 29, pp. 73-84.

Tamulewicz J., 1997. Pogoda i klimat Ziemi [in:] Wielka Encyklopedia Geografii Świata. Poznań: Wydawnictwo Kurpisz, V, pp. 294-296.

Woś A., 2010. Klimat Polski w drugiej połowie XX wieku. Poznań: Wydawnictwo Naukowe UAM, $489 \mathrm{pp}$. 
